\title{
Black Book Reviewing: A Case for Library Action
}

\begin{abstract}
Although the rate at which books by and about blacks has increased rapidly during the past few years, there has been no corresponding increase in the publication of reviews and indexes for these new books. In order to select the best available materials for library collections and Black Studies programs, librarians must be able to locate reviews that do exist on these books. In addition, librarians will have to make demands on the predominantly white book media to include and more carefully select reviews on books by and about blacks.
\end{abstract}

\section{M} ORE BOOKS BY AND ABOUT BLACKS are being printed than ever before in publishing history. An article, which appeared in the June 1971 issue of Sepia magazine entitled "The Black Book Boom," estimated $\$ 60,000,000$ as the current retail value of black books being published. Needless to say, it is now more. A modicum of these are distributed by small, newly established black publishers. The effects of this deluge of black materials on libraries and librarians are both devastating and frustrating.

To attempt to purchase all books on black themes now streaming off the presses, no matter how much material is needed to fill in gaps and support Black Studies programs, is virtually impossible. Limited budgets, the need to balance the book collection, relevancy of the materials, and quality are all factors that have to be taken into consideration.

The criteria for establishing a good basic black book collection should be quality. The task of discarding quickie books on blacks from the ones that pro-

Ann Allen Shockley is associate librarian, and head, Special Collections, Fisk University Library, Nashville, Tennessee. mote honest scholarship and present meaningful literary insights into the black experience is indeed an important one.

In order for librarians to be selective in buying books by and about blacks, they should familiarize themselves with the few available tools for selecting these materials. In applying professional knowledge to book selection, librarians can either examine the book if a copy is available and time permits, or read reviews about the book. For reviewing purposes, librarians can rely on the standard basic tools such as Choice, $\mathrm{Li}$ brary Journal, American Libraries, Booklist, and other journals. It is tragic to note, however, that few of these references give even a minimum amount of attention to reviewing books by and about blacks.

A few noted and established black writers-James Baldwin, Julius Lester, Ernest J. Gaines, John Edgar Wideman, John A. Williams, and Ronald Fairare reviewed in the white book media. These authors are published by major white publishers who can and do exert influence on the book reviewing hierarchy. Yet other black authors, who are writing on a comparable if not higher level are not reviewed in these journals. 
The revolutionary novel by Sam Greenlee, The Spook Who Sat by the Door, was a bestseller in London, and ended up a bestseller when it finally appeared in this country. When Greenlee was questioned about where it had been reviewed during a lecture at Fisk University on April 22, 1971, he replied that only the Johnson City, Tennessee Chronicle had bothered to review it. Further search showed the book was noted in Jet magazine, but not reviewed.

Books by black authors do not get the attention of the reviewing channels for various reasons: (1) some reviewers do not think the books are worthy of reviewing; (2) space limitations exist for reviews; (3) the books are judged of no interest to readers of the publication; (4) publishers do not press for reviews; and (5) the books are not sent to be reviewed. The underlying reason, however, was aptly pointed out by black librarian and publisher of Broadside Press, Dudley Randall, who blames it on racism in the reviewing media. In the much publicized and discussed article, "Why Minority Publishing?" which appeared in the March 15, 1971 issue of Publishers' Weekly, he noted that books by black Pulitzer-prize-winning Gwendolyn Brooks were widely reviewed when published by Harper. But her recent book, Riot, published by Broadside Press, had been received with almost total silence. Okechukwu Mezu, publisher of Black Academy Press, in the same article agreed that his main problem in the book reviewing media was its failure to review his books.

Although white publishers may retort that they too have the same problem, it is not of the same magnitude. The hard fact is that whites control reviewing services and publications. There is no doubt that these sources are powers which repress and influence the dissemination of black reviewing information.

In the twilight of this gray picture tinged with racism, where can librarians turn to obtain reviews and announce- ments of books by and about blacks, both scholarly and popular? Publishers' Weekly does not strain to announce titles by Broadside Press, Third World Press, Third Press, Drum and Spear, Afro-Am, and other minority publishers. Librarians should be able to find reviews in Book Review Digest. This widely-used compilation should seemingly review black titles that are under consideration for purchasing. But what does Book Review Digest index? It purports to index reviews of current fiction and nonfiction in selected periodicals. Unhappily, the Digest does not list one black periodical for indexing in its array of selected titles.

This raises questions. Who makes the selection of periodicals for reviewing? In the prefatory note, Book Review Digest states that it is done by subscribers' votes. Who are the subscribers? Don't the subscribers, certainly libraries, realize the importance of black periodicals and journals in this age?

To qualify for inclusion in Book Review Digest, a work of nonfiction must have received two or more reviews, and for fiction, four or more reviews in the selected journals. Thus, if only one white selected journal reviews one book of black fiction or nonfiction, that book will not qualify for inclusion. As black titles and books by black authors are not extensively reviewed in white reviewing publications, it is obvious that few will reach Book Review Digest.

The Book Review Index, first published by Gale during 1965-68, is a guide to current reviews of books. Four black publications are indexed. These are the Journal of Negro Education, Journal of Negro History, Negro Digest (now Black World), and the Negro History Bulletin. The Journal of Asian Studies is indexed but not the Journal of African Studies.

One can find review information and announcements on black materials primarily in black publications and services designed for disseminating this infor- 


\section{8 / College \& Research Libraries • January 1974}

mation. Unfortunately, many librarians have not resorted to using these sources: some lack knowledge about them; sometimes libraries do not subscribe to them; and a few are professionally indifferent and negligent.

One bibliographic service that lists and annotates books by and about blacks (current and reprints) is the Bibliographic Survey: The Negro in Print, published in Washington, D.C., with Beatrice Murphy as managing editor. This service began in May 1965, and many libraries subscribe to it. The service lists nonfiction, fiction, books for young readers, periodicals, paperbacks, and reprints. The publishing policy states: "Its purpose is to inform and let the reader form his own opinion."

As librarians are aware, in book selection a decision for purchasing cannot be effectively made from a book annotation. The book might sound interesting and be needed for the collection, but it might not meet the criteria for occupancy on a library shelf. There might be another work on the same topic better written, more timely, and treated by a more knowledgeable author. The Bibliographic Survey is valuable for book news, but not for reviews.

There currently is one pertinent index for locating reviews on books although slow in publication. The Index to Selected Periodicals, published by G. K. Hall since 1950, indexes black periodicals and journals. There is a subject listing in the Index under "Book Reviews." The entries include the name of the author, title of the book, name and date of the periodical in which the review appeared, and the reviewer. With more and more black publications coming into being, the publishers in the 1971 Annual Index to Periodical Articles by and about Negroes, published in 1973 , have broadened the scope to include "significant Black journals which are either not indexed or incompletely indexed elsewhere." Eight new titles have been added.
A new index, Black Information Index, was an outgrowth of the subcommittee on Negro Research Libraries, an extension of the COASTI Task Group on Library Programs of the Committee on Scientific and Technical Information, which had its maiden printing in 1970. To date, four issues have been published. Whether this index will remain in print is questionable. The publication, now in limbo, scanned over eighty newspapers and journals, major white ones included, providing current information and news about black people. Book reviews are one of the fortyone categories listed. Here the entry is under the title of the book. The author is listed next, with bibliographic information, the name of the reviewer, and location of the review.

The most current listing for black book reviews is the Black Books Bulletin, which is published quarterly by the Institute of Positive Education in Chicago, Illinois. The Black Books Bulletin has an attractive format, and contains critical reviews of books by and about black people on all subjects. There is a list of current, annotated books, news from black publishers, and reviews about children's books.

After locating reviews of these books, the kinds of periodicals in which they appear and the reviewers must be examined. Frequently, book reviews published in periodicals other than professional library journals do not help librarians with book selection. Some simply describe a book, others are geared for a particular reader interest, and some are intended to promote an author, or book sales.

When reading reviews about black titles in a black publication, something should be known about the publication itself. How is the periodical slanted toward black nationalism or moderation; black middle-class orientation; scholarly or popular?

Next, special attention should be given to the reviewers. Are most reviews of 
books by black authors favorable because the reviewers are biased, realizing that black authors have too long been ignored in publishing circles? Do they feel obligated to help the brothers and sisters? Do the reviewers lean toward the left and totally disregard a good scholarly work or excellent piece of literary writing because they do not personally agree with the author's point of view? Conversely, are the white reviewers of titles by black authors racially influenced, too critical in comparison with other works on the same subject by white authors, and heedless of the unique black experience in American life that has nurtured and limited the author's insight, ability, and experience?

There are black journals which publish excellent book reviews by knowledgeable black as well as white scholars and researchers in various academic fields. The reviews are extensive, wellwritten, and many take the form of an essay. The number of reviews vary each issue, possibly because of space limitations.

The Journal of Negro History, issued quarterly by the esteemed organization of the Association for the Study of Afro-American Life and History, which has pioneered in the publishing of black history since 1916, averages fifty book reviews a year on historical and related topics. Its companion publication, the Negro History Bulletin, geared for elementary and secondary schools, as well as for universities and colleges, is published eight times a year. Approximately two to four reviews are published in each issue.

Literary quarterlies of black academic institutions and organizations present quality reviews. The prestigious College Language Association journal reviews over sixteen publications a year. Announcements are included of recent black publisher's books, and of works by and about blacks. Phylon, a publication of Atlanta University, reviews books under the caption "Literature of
Race and Culture." The number of reviews has dwindled somewhat in the past year and vary from one to two, and in a few instances, none.

Freedomways, published by Freedomways Associates, Inc., reviews approximately sixteen books a year. The outstanding feature of this quarterly is its extensive, annotated list of recent books in all subject areas. This list sometimes numbers over 150 titles per issue. Full bibliographic information is given and additional titles on similar subjects or themes are pointed out in the annotations. These features are of special interest to librarians. The Black Scholar, published monthly except for July and August by the Black World Foundation, publishes one to two reviews per issue.

The laudable little magazine, Black World, carries about two to three reviews monthly. Often, however, it does not fully identify the reviewers. The notes on books and writers are valuable for information on black writers, publishing news, and literary perspectives. The librarian seeking reviews of black titles should be able to distinguish a review from a mere description or blurb as those that appear in the popular, slick Ebony and Essence, and news magazine, Jet.

The problem of finding good, reliable reviews about books by and about blacks is important to librarians. Presently, publishers are dashing off at an astronomical rate inferior works with black themes. Many are slipshod, pseudo-scholarly works published to cash in on the black bonanza by instant black experts while the demand is heavy.

In glancing through new titles, it is apparent that anthologies are now in vogue and leading the lists. The rash of anthologies which some editors have published are collections with almost repetitious titles, making it more confusing to librarians. These are evidenced in such collections as: AW. E. B. DuBois Reader, edited by Andrew G. 
Paschal, and W. E. B. DuBois: A Reader, edited by Meyer Weinberg; Black Drama: An Anthology edited by William Brasmer and Dominick Consolo, and Black Drama Anthology, edited by Woodie King; and The Black Soldier, edited by Jesse J. Johnson, and The Black Soldier, edited by Jay David and Elaine Crane.

Collections of biographies are also repetitive in content. For example, both books, Negroes of Achievement in Modern America by James J. Flynn, and Black Profiles, edited by George R. Metcalf, have chapters on Roy Wilkins, Thurgood Marshall, Martin Luther King, Jr., James Howard Meredith, Medgar Wiley Evers, and Jackie Robinson.

Frequently, similar chapters excerpted from books are used in different collections. In Melvin Drimmer's work with the grossly misleading title, Black History: A Reappraisal (which is a collection of articles rather than a firsthand appraisal) a chapter is included on "The Background of the Harlem Renaissance" which appeared in Robert A. Bone's classic The Negro Novel in America. The same chapter is repeated in Eric Foner's America's Black Past: A Reader in Afro-American History. Other writers who have written on the background of the Harlem Renaissance could certainly be included in collections; but they are ignored by slovenly editors out to make a quickie publishing name by capitalizing on books by and about blacks.

If librarians, both black and white, learn to be more selective in purchasing titles by or about blacks and let the publisher know their criteria, perhaps then, publishers will become more selective in printing works that librarians can point to with professional pride as excellent sources for research or reader interest on blacks. In order to do this, librarians must let the publishers know that they are aware of the current mass publication of inferior works, repetitious subject matter, and misleading titles. Publishers must be made to realize that librarians are not going to rush blindly to purchase any book with the word black in the title for Black Studies programs and collections without any professional inquiry.

Black librarians, in particular, must be hypercritical and more vocal in evaluating books on black themes and by black authors. Even though a book is by a black author and is about blacks, they must ask if it really gives true insight into black life or black scholarship. These librarians, above all, should be thorns in the side of the white publishing establishment. They should work more closely with black publishers in selecting books relevant and true to the black experience. More black librarians should be invited to review books for white publications and also for black ones, particularly in the juvenile and young adult fields.

Now is the time for the library profession to pressure the book reviewing media to index black publications and to review more books by and about blacks. These should include those published by black publishers. Librarians must contribute to the free flow of black information and influence media in the book publishing establishment.

Today, the black man is being exploited in book publishing. The Indian appears to be next in line, and possibly later, the Chicanos, Puerto Ricans, and alas, even the Eskimos, and librarians will be continuously beleaguered with a flood of miscellaneous print.

Librarians, face the challenge and act! Soon we may be like the tired, old black farmer in the classic joke, who had labored so long and hard under the hot sun, that finally one day, he dropped his plow in the middle of the dusty field, looked up to the sky and said: "Oh, Lawd, ah'm so tired, ah think ah done been called to preach!" 